\title{
Pengaruh Penambahan Tepung Kacang Tanah (Arachis hypogaea L.) terhadap Daya Terima, Kadar Air, dan Kadar Protein Nugget Edamame (Glycin max (L) Merril)
}

\section{The Effect of Peanut Flour (Arachis hypogaea L.) Addition against The Acceptance, Water Level, and Protein Level of Edamame Nugget (Glycin max (L) Merril)}

\author{
Nevi Ruliyana Santi ${ }^{1}$, Farida Wahyu Ningtyas ${ }^{1 *}$, Sulistiyani ${ }^{1}$
}

\begin{abstract}
ABSTRAK
Latar Belakang: Kedelai edamame merupakan jenis kedelai di Kabupaten Jember yang jumlahnya melimpah, harganya murah, tetapi pengolahan dan pemanfaatannya masih kurang terutama dalam bentuk lauk.

Tujuan: Penelitian ini bertujuan untuk menganalisis pengaruh penambahan tepung kacang tanah terhadap daya terima, kadar air, dan kadar protein nugget edamame.

Metode: Jenis penelitian termasuk quasi eksperimental menggunakan posttest only control group design dengan 4 taraf perlakuan: $\mathrm{X}_{0}, \mathrm{X}_{1}, \mathrm{X}_{2}$, dan $\mathrm{X}_{3}$ (nugget edamame tanpa penambahan tepung kacang tanah (kontrol), dengan penambahan 10\%, 20\%, dan 30\%) dan 16 unit percobaan. Semua taraf perlakuan akan dianalisis daya terima dengan form Hedonic Scale Test di Sekolah Menengah Pertama Islam Terpadu (SMPIT) Al Ghozali Jember, kadar air dengan metode destilasi dan kadar protein dengan uji Semi Mikro Kjeldahl di Laboratorium Analisis Pangan Politeknik Negeri Jember.

Hasil: Hasil penelitian menunjukkan penambahan tepung kacang tanah dapat meningkatkan daya terima (rasa, warna, dan tekstur), kadar air, dan kadar protein nugget edamame. Perlakuan yang paling disukai panelis dari aspek rasa adalah nugget edamame dengan penambahan tepung kacang tanah sebanyak 30 gram, dari aspek warna dan aroma adalah nugget edamame tanpa penambahan tepung kacang tanah, dan dari aspek tekstur adalah nugget edamame dengan penambahan 10 gram kacang tanah. Perlakuan dengan kadar air dan kadar protein tertinggi adalah nugget edamame dengan penambahan tepung kacang tanah sebanyak 30 gram.

Kesimpulan: Terdapat pengaruh penambahan tepung kacang tanah terhadap daya terima (rasa, warna, dan tekstur), kadar air, dan kadar protein nugget edamame.
\end{abstract}

Kata kunci: daya terima, kadar air, kadar protein, nugget edamame, tepung kacang tanah 


\begin{abstract}
Background: Edamame is one of local food in Jember Regency which overflow followed, cheap, but its cultivation and utilization is deficient, especially in the form as a side dishes.

Objectives: This research aimed to analyze the effect of peanut flour addition to the acceptance, water level, and protein level of edamame nugget.

Methods: This research is Quacy Experimental with posttest only control group design with 4 treatments: $X 0, X 1, X 2$, and $X 3$ (edamame nugget without addition, with $10 \%$ addition, $20 \%$, and $30 \%)$ and 16 units experiment. The acceptance will be analyzed with form Hedonic Scale Test, water level with destilation test, and protein level with Semi Mikro Kjeldahl test in Food Analysis Laboratory of Polytechnic Jember.
\end{abstract}

Results: The results from this research showed the addition of peanut flour can increase accpetance (flavor, color, and texture), water level, and protein level of edamame nugget. $X 3$ is most preferred from taste aspect, $X O$ is most preferred from color and aroma aspect, and X1 most preferred from texture aspect. The treatment with high water level and protein level is X3.

Conclusion: there are significant addition of peanut flour againts the acceptance, water level, and protein level of edamame nugget.

Keywords: acceptance, water level, protein level, edamame nugget, peanut flour

\footnotetext{
*Koresponden:

farida-.fkm@unej.ac.id

${ }^{1}$ Departemen Gizi Kesehatan Masyarakat,

Fakultas Kesehatan Masyarakat-Universitas Jember
} 


\section{PENDAHULUAN}

Kedelai edamame merupakan salah satu pangan lokal jenis kedelai yang dikembangkan di Kabupaten Jember ${ }^{1}$. Kedelai edamame umumnya dikonsumsi sebagai camilan yaitu dengan di-blanching atau direbus $^{2}$. Kedelai edamame tidak hanya dapat digunakan sebagai camilan, tetapi juga dapat diolah menjadi produk yang cukup digemari oleh masyarakat, seperti nugget. Nugget pada umumnya dibuat dari daging ayam yang harganya cukup mahal, sehingga tidak semua orang dapat menikmatinya ${ }^{3}$. Kandungan gizi kedelai edamame juga tidak kalah dengan bahan pangan hewani. Menurut Sciarappa ${ }^{4}$, kedelai edamame tidak mengandung kolesterol dan lemak jenuh, juga mengandung asam amino yang dibutuhkan tubuh. Oleh karena itu, kedelai edamame dapat menjadi alternatif lain untuk membuat nugget.

Pemilihan kedelai edamame ini karena jumlahnya cukup banyak, harganya relatif terjangkau, dan kandungan gizinya cukup baik. Kandungan gizi pada $100 \mathrm{~g}$ kedelai edamame berupa $11 \mathrm{~g}$ karbohidrat, 12,4 g protein, 145 $\mathrm{mg}$ kalsium, $158 \mathrm{mg}$ fosfor, selain itu juga rendah kolesterol dan kaya serat ${ }^{1}$. Kedelai edamame cocok untuk dikonsumsi oleh konsumen yang menginginkan makanan rendah lemak tetapi tinggi protein. Vegetarian disarankan untuk mengkonsumsi kedelai karena mengandung protein lengkap, yaitu asam amino yang diperlukan tubuh ${ }^{5}$.

Nugget edamame akan ditambahkan tepung kacang tanah dengan proporsi tertentu dengan tujuan untuk meningkatkan kadar protein dan cita rasa dari nugget edamame. Nugget dengan rasa yang gurih dan kandungan gizi yang baik, diharapkan tidak hanya dapat dikonsumsi oleh masyarakat vegetarian, tetapi juga dapat dikonsumsi oleh penderita Kurang Energi Protein (KEP). Berdasarkan uraian tersebut, maka penelitian ini bertujuan untuk menganalis pengaruh penambahan tepung kacang tanah dengan proporsi berbeda yaitu 0\% (0 gram), 10\% (10 gram), 20\% (20 gram), dan 30\% (30 gram) terhadap daya terima, kadar air dan kadar protein nugget edamame.

\section{METODE}

Jenis penelitian yang digunakan adalah quasi experimental dengan desain Posttest Only Control Group Design. Terdapat 4 taraf perlakuan penelitian, yaitu $X_{0}$ (kontrol, tanpa penambahan tepung kacang tanah), $X_{1}$ dengan penambahan tepung kacang tanah $10 \%(10 \mathrm{~g})$, $X_{2}$ dengan penambahan $20 \%(20 \mathrm{~g})$, dan $X_{3}$ dengan penambahan $30 \%$ (30 g). Jumlah pengulangan (replikasi) yang dilakukan adalah 4 kali, sehingga total sampel penelitian adalah 16 sampel dengan 4 sampel kontrol dan 12 sampel perlakuan. Variabel bebas dari penelitian ini adalah penambahan tepung kacang tanah, sedangkan yang menjadi variabel terikat adalah daya terima, kadar air dan kadar protein.

Nugget edamame dibuat dengan mencampur kedelai edamame giling dengan tepung kacang tanah ditimbang sesuai perlakuan bersama bumbu hingga merata. Adonan kemudian dibungkus dengan daun pisang, dikukus lebih kurang 20 menit sampai matang. Adonan yang telah didinginkan kemudian dipotong sesuai keinginan. Potongan nugget selanjutnya dimasukkan dalam kocokan telur, dibalur tepung roti, untuk digoreng sampai berwarna kuning kecokelatan. Komposisi masing-masing bahan disajikan pada Tabel 1.

Tabel 1. Komposisi Adonan Nugget Masingmasing Perlakuan

\begin{tabular}{|c|c|c|c|c|}
\hline \multirow{2}{*}{ Bahan } & \multicolumn{4}{|c|}{ Jumlah } \\
\hline & $x_{0}$ & $X_{1}$ & $X_{2}$ & $X_{3}$ \\
\hline $\begin{array}{l}\text { Kedelai edamame } \\
\text { (g) }\end{array}$ & 100 & 100 & 100 & 100 \\
\hline $\begin{array}{l}\text { Tepung } \quad \text { kacang } \\
\operatorname{tanah}(\mathrm{g})\end{array}$ & 0 & 10 & 20 & 30 \\
\hline Tepung tapioka (g) & 100 & 90 & 80 & 70 \\
\hline Bawang putih (g) & 5 & 5 & 5 & 5 \\
\hline Garam (g) & 3 & 3 & 3 & 3 \\
\hline Merica bubuk (g) & 1 & 1 & 1 & 1 \\
\hline Telur (butir) & 1 & 1 & 1 & 1 \\
\hline
\end{tabular}


Penelitian dilakukan mulai Mei 2016 sampai Januari 2017 yang dilaksanakan di Laboratorium Analisis Pangan Politeknik Negeri Jember untuk kadar air dan kadar protein. Uji daya terima dilaksanakan pada siswa-siswi Sekolah Menengah Pertama. Analisis yang dilakukan adalah uji daya terima (Hedonic Scale Test) meliputi rasa, warna, aroma dan tekstur dengan jumlah panelis tidak terlatih sebanyak 25 orang. Panelis diminta mengisi form dengan kriteria penilaian sebagai berikut: 3 (sangat suka), 2 (biasa saja), 1 (tidak suka). Analisis kadar air menggunakan metode destilasi dan kadar protein menggunakan metode Semi Mikro Kjeldahl. Hasil uji daya terima terima akan dianalisis menggunakan uji Friedman, sedangkan hasil uji kadar air dan kadar protein masing-masing akan dianalisis menggunakan uji KruskallWallis.

\section{HASIL DAN PEMBAHASAN}

Pengaruh penambahan tepung kacang tanah terhadap daya terima, kadar air, dan kadar protein nugget edamame dapat dijelaskan sebagai berikut :

\section{Rasa}

Berdasarkan hasil uji Hedonic Scale Test, nugget edamame dengan nilai rata-rata tertinggi dari aspek rasa adalah $X_{3}$, yaitu dengan penambahan tepung kacang tanah 30 gram. Sedangkan nilai rata-rata terendah adalah $\mathrm{X}_{0}$, yaitu kontrol (tanpa penambahan tepung kacang tanah). Hal ini menunjukkan bahwa nugget edamame dengan penambahan tepung kacang tanah 30 gram paling disukai oleh panelis, dibandingkan dengan nugget edamame tanpa penambahan tepung kacang tanah. Hasil uji Hedonic Scale Test rasa dapat dilihat pada Gambar 1.

Menurut hasil analisis daya terima rasa menggunakan uji Friedman dapat diketahui bahwa $p$-value $(0,024)<\alpha(0,05)$ sehingga $\mathrm{H}_{0}$ ditolak, artinya terdapat perbedaan yang signifikan pada penambahan tepung kacang tanah terhadap daya terima rasa. Rasa kedelai edamame adalah gurih dan manis. Ketika kedelai edamame dihaluskan, rasanya menjadi agak langu. Hal inilah yang menyebabkan nugget edamame tanpa penambahan tepung kacang tanah kurang disukai. Sedangkan nugget edamame dengan penambahan tepung kacang tanah 30 gram memiliki rasa yang lebih gurih di antara perlakuan yang lain. Rasa gurih ini dapat diakibatkan oleh cukup tingginya kadar lemak pada kacang tanah. Lemak yang terkandung di dalam kacang tanah adalah lemak tersembunyi (infisible fat), karena termakan langsung dengan bahan, bukan sengaja ditambahkan. Lemak ini dapat menambah kalori, memperbaiki tekstur, dan cita rasa bahan pangan ${ }^{13}$. Oleh karena hasil uji Friedman menunjukkan bahwa $\mathrm{H}_{0}$ ditolak, maka diperlukan analisis lanjutan menggunakan uji Wilcoxon Signed Rank Test untuk mengetahui perbedaan dari masingmasing kelompok sampel. Berdasarkan analisis lanjutkan, didapatkan hasil bahwa terdapat dua pasangan perlakuan yang memiliki perbedaan yang siginifikan, yaitu perlakuan $X_{0}-X_{3}$ (perlakuan nugget tanpa penambahan tepung kacang tanah dengan perlakuan nugget dengan penambahan kacang tanah 30 gram) dan $\mathrm{X}_{1}-\mathrm{X}_{3}$ (perlakuan nugget

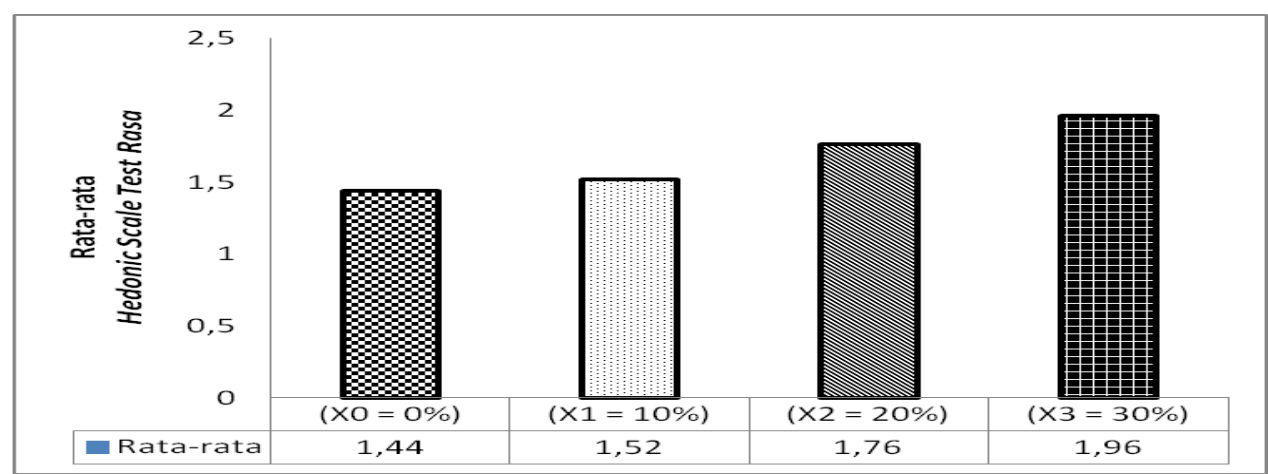

Gambar 1. Rata-rata Uji Hedonic Scale Test Rasa 


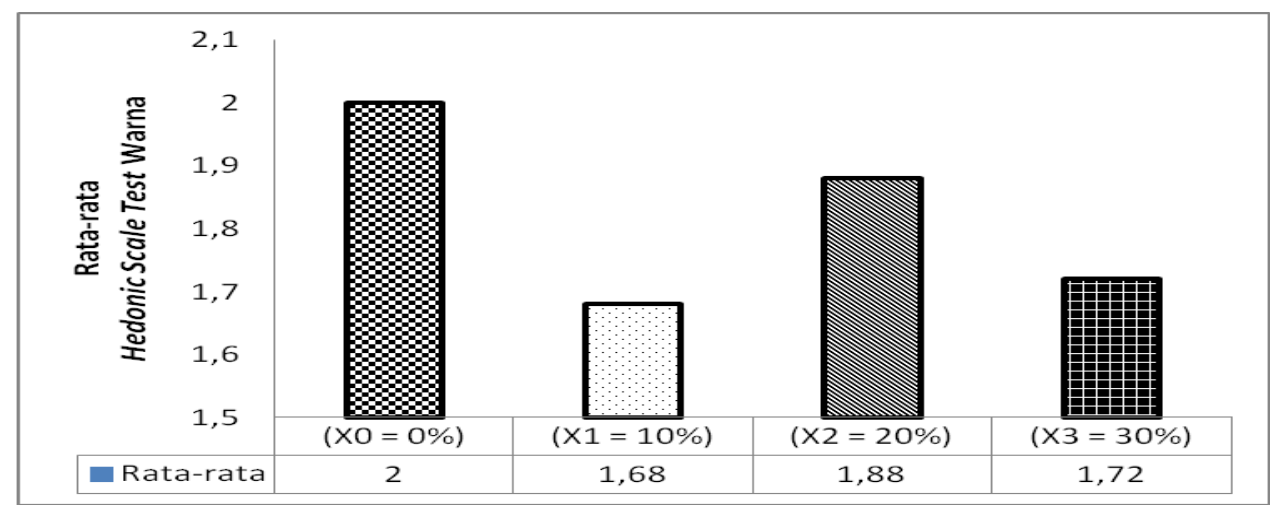

Gambar 2. Rata-rata Uji Hedonic Scale Test Warna

dengan penambahan tepung kacang tanah 10 gram dengan perlakuan nugget dengan penambahan tepung kacang tanah 30 gram).

\section{Warna}

Berdasarkan hasil uji Hedonic Scale Test, nilai rata-rata tertinggi dari segi warna adalah $X_{0}$ yaitu kontrol (tanpa penambahan tepung kacang tanah). Sedangkan nilai ratarata terendah adalah $X_{1}$ dengan penambahan tepung kacang tanah 10 gram. Hal ini menunjukkan bahwa nugget edamame tanpa penambahan tepung kacang tanah lebih disukai dibandingkan perlakuan lain, dan nugget edamame dengan penambahan tepung kacang tanah 10 gram kurang disukai panelis. Hasil uji Hedonic Scale Test warna dapat dilihat pada Gambar 2. Menurut hasil analisis daya terima rasa menggunakan uji Friedman dapat diketahui bahwa $p$-value $(0,044)<\alpha(0,05)$ sehingga $\mathrm{H}_{0}$ ditolak, artinya terdapat perbedaan yang signifikan pada penambahan tepung kacang tanah terhadap daya terima warna. Warna nugget edamame tanpa penambahan tepung kacang tanah paling disukai karena perlakuan ini lebih didominasi oleh warna kehijauan dari kedelai edamame. Sedangkan perlakuan $X_{1}$ (dengan penambahan tepung kacang tanah 10 gram) kurang disukai. Peningkatan penambahan tepung kacang tanah membuat warna nugget edamame menjadi lebih kecokelatan.

Warna yang lebih kecokelatan ini juga disebabkan karena reaksi Maillard sebagai interaksi antara gugus amino, peptida atau protein dengan gugus hidroksil glikosidik pada gula reduksi. Reaksi Maillard terjadi pada bahan yang mengandung gula dan protein tinggi yang mengalami pemanasan sehingga menimbulkan warna cokelat ${ }^{6}$. Untuk warna luar nugget juga sangat dipengaruhi oleh waktu dan suhu penggorengan, serta pencelupan ke dalam batter (telur) dan pelapisan dengan breader (tepung roti). Waktu dan suhu penggorengan yang digunakan seharusnya 2 menit dengan suhu $190-192^{\circ} \mathrm{C}^{7}$, sedangkan pada perlakuan ini tidak diperhatikan suhu dan tebal tipis dari batter dan breader, hanya diperhitungkan nyala api dan waktu penggorengan yang sama. Akibat tidak diperhitungkannya standarisasi proses pembuatan, membuat perlakuan $X_{1}$ menjadi hangus atau gosong, sehingga warnanya lebih cokelat gelap dan kurang disukai. Oleh karena itu, diperlukan analisis lanjutan dengan uji Wilcoxon Signed Rank Test yang bertujuan untuk mengetahui perbedaan dari masing-masing kelompok sampel. Hasil uji Wilcoxon Signed Rank Test menjelaskan bahwa perbedaan yang signifikan dimiliki oleh pasangan perlakuan $X_{0}-X_{1}$ (perlakuan nugget tanpa penambahan tepung kacang tanah dengan perlakuan nugget dengan penambahan tepung kacang tanah 10 gram) dan $\mathrm{X}_{0}-\mathrm{X}_{3}$ (perlakuan nugget tanpa penambahan tepung kacang tanah dengan perlakuan nugget dengan penambahan tepung kacang tanah 30 gram).

\section{Aroma}

Berdasarkan hasil uji Hedonic Scale Test, nilai rata-rata tertinggi dari segi aroma adalah $\mathrm{X}_{0}$, yaitu kontrol (tanpa penambahan tepung kacang tanah). Sedangkan nilai rata- 
rata terendah adalah $\mathrm{X}_{2}$ dengan penambahan tepung kacang tanah 20 gram. Hal ini menunjukkan bahwa aroma nugget edamame tanpa penambahan tepung kacang tanah lebih disukai dibandingkan dengan nugget dengan penambahan tepung kacang tanah. Perlakuan nugget edamame dengan penambahan tepung kacang tanah 20 gram adalah perlakuan yang paling kurang disukai panelis. Hasil uji Hedonic Scale Test aroma ini dapat dilihat pada Gambar 3.

Aroma nugget edamame tanpa penambahan tepung kacang tanah lebih disukai karena memiliki aroma yang dianggap biasa oleh panelis, yaitu aroma campuran dari kedelai edamame dengan tepung tapioka juga dari bawang putih. Sedangkan pada perlakuan selanjutnya, aroma nugget mulai berubah seiring dengan peningkatan penambahan tepung kacang tanah. Tanggapan terhadap aroma seringkali diasosiasikan dengan aroma produk/senyawa yang sudah umum dikenal seperti vanili, mentega, assam butirat, dan sebagainya ${ }^{8}$, sehingga aroma kedelai edamame terpengaruh dengan aroma kacang tanah. Pada penelitian yang ada membuktikan bahwa semakin tinggi tepung bungkil kacang tanah yang ditambahkan pada mie, mengakibatkan panelis kurang menyukai aroma mie tersebut ${ }^{9}$.

Menurut hasil analisis daya terima rasa menggunakan uji Friedman dapat diketahui bahwa $p$-value $(0,479)>\alpha(0,05)$ sehingga $H_{0}$ ditolak, artinya tidak terdapat perbedaan yang signifikan penambahan tepung kacang tanah terhadap daya terima aroma dari nugget edamame dan tidak membutuhkan analisis lanjutan untuk mengetahui perbedaan masing-masing perlakuan.

\section{Tekstur}

Berdasarkan hasil uji Hedonic Scale Test, nilai rata-rata tertinggi dari segi tekstur adalah $X_{1}$, yaitu dengan penambahan tepung kacang tanah 10 gram. Sedangkan nilai rata-rata terendah adalah $\mathrm{X}_{3}$, yaitu dengan penambahan tepung kacang tanah 30 gram. Hal ini menunjukkan bahwa tekstur nugget edamame yang paling disukai adalah nugget dengan penambahan tepung kacang tanah 10 gram, dan nugget yang kurang disukai adalah nugget dengan penambahan tepung kacang tanah 30 gram. Hasil uji Hedonic Scale Test tekstur dapat dilihat pada Gambar 4.

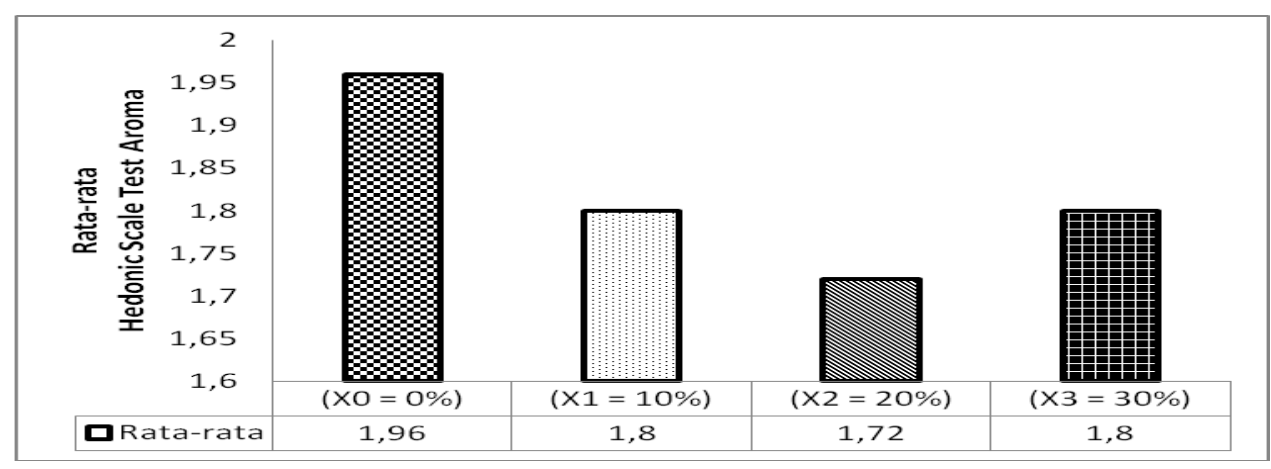

Gambar 3. Rata-rata Uji Hedonic Scale Test Aroma

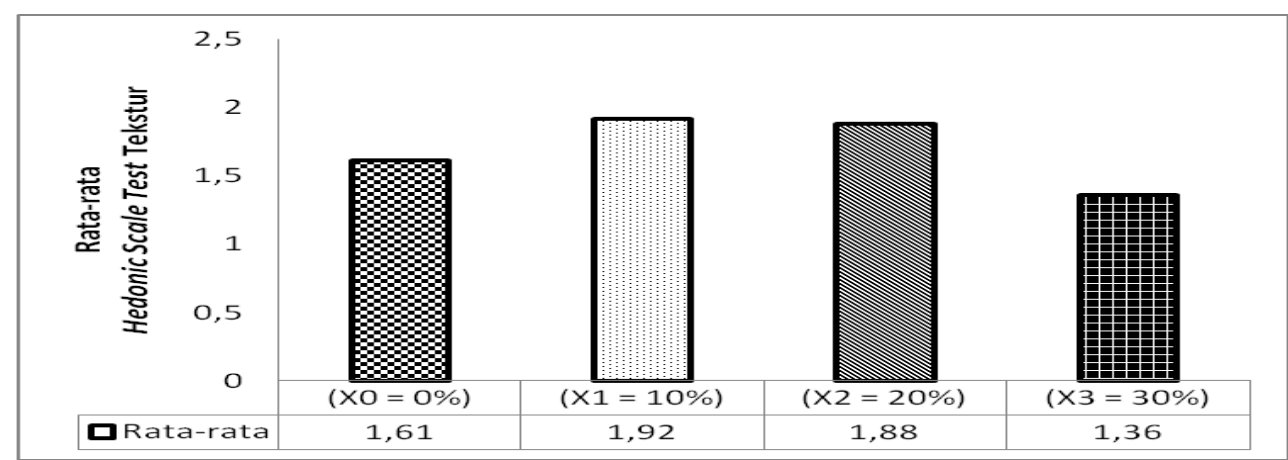

Gambar 4. Rata-rata Uji Hedonic Scale Test Tekstur 
Tekstur bagian dalam nugget yang baik adalah lunak kenyal, apabila digigit tidak keras tetapi juga tidak lembek. Tekstur bagian luarnya keras karena tepung roti/panir yang melekat ${ }^{10}$. Tekstur yang paling disukai adalah perlakuan dengan penambahan tepung kacang tanah 10 gram. Nugget perlakuan ini tidak keras, tidak terlalu lembek dan kenyal, berbeda dengan perlakuan dengan penambahan tepung kacang tanah 30 gram yang memang lebih lembek. Nugget edamame ini juga didominasi oleh tepung tapioka. Penelitian Karti et al., 2013, semakin tinggi penggunaan tepung tapioka pada bakso, tekstur dari produk yang dihasilkan akan semakin kenyal ${ }^{11}$. Sifat tepung tapioka yang mampu menyerap air dan dapat menampilkan bentuk yang padat, membuat bakso terlihat lebih padat tetapi tetap lembek.

Menurut hasil analisis daya terima rasa menggunakan uji Friedman dapat diketahui bahwa $p$-value $(0,001)<\alpha(0,05)$ sehingga $\mathrm{H}_{0}$ ditolak, artinya terdapat perbedaan yang signifikan pada penambahan tepung kacang tanah terhadap daya terima tekstur. Oleh karena itu membutuhkan analisis lanjutan dengan uji Wilcoxon Signed Rank Test untuk mengetahui perbedaan secara nyata dari masing-masing perlakuan. Hasil uji Wilcoxon menunjukkan bahwa perbedaan yang signifikan dimiliki oleh pasangan perlakuan $X_{1}-X_{3}$ (perlakuan nugget edamame dengan penambahan 10 gram tepung kacang tanah dengan perlakuan nugget edamame dengan penambahan 30 gram tepung kacang tanah) dan $\mathrm{X}_{2}-\mathrm{X}_{3}$ (perlakuan nugget edamame dengan penambahan 20 gram tepung kacang tanah dengan perlakuan nugget edamame dengan penambahan 30 gram tepung kacang tanah).

\section{Kadar Air}

Berdasarkan hasil uji laboratorium, diketahui bahwa nilai rata-rata kadar air tertinggi adalah perlakuan $X_{3}(44,61 \%)$ dan nilai rata-rata terendah adalah perlakuan $X_{0}$ $(43,28 \%)$. Hasil uji kadar air dapat dilihat pada Gambar 5. Menurut hasil statistik uji KruskallWallis menunjukkan bahwa $p$-value $(0,003)<$ $\alpha(0,05)$ sehingga $H_{0}$ ditolak, artinya terdapat perbedaan kadar air yang signifikan pada nugget edamame dengan atau tanpa penambahan tepung kacang tanah. Nugget edamame yang memiliki kadar air tertinggi adalah $X_{3}$ dengan penambahan tepung kacang tanah $30 \%$. Penambahan tepung kacang tanah yang semakin meningkat mengakibatkan peningkatan kadar air pada nugget. Peningkatan ini dapat disebabkan oleh perbedaan jenis bahan dasar yang digunakan. Perlakuan $X_{0}$ hanya tersusun dari kedelai edamame dan tepung kacang tanah, sehingga kadar airnya paling rendah. Sedangkan perlakuan $X_{1}$ mendapatkan penambahan tepung kacang tanah 10 gram, $X_{2}$ mendapatkan penambahan tepung kacang tanah 20 gram, dan $X_{3}$ mendapatkan penambahan tepung kacang tanah 30 gram, sehingga kadar airnya bertambah. Kadar air pada kedelai edamame sebesar $7,5 \mathrm{~g}$, tepung tapioka 9,1 g, dan tepung kacang tanah 9,6 $\mathrm{g}^{12}$. Kadar air suatu bahan pangan berpengaruh besar terhadap daya tahan bahan pangan,

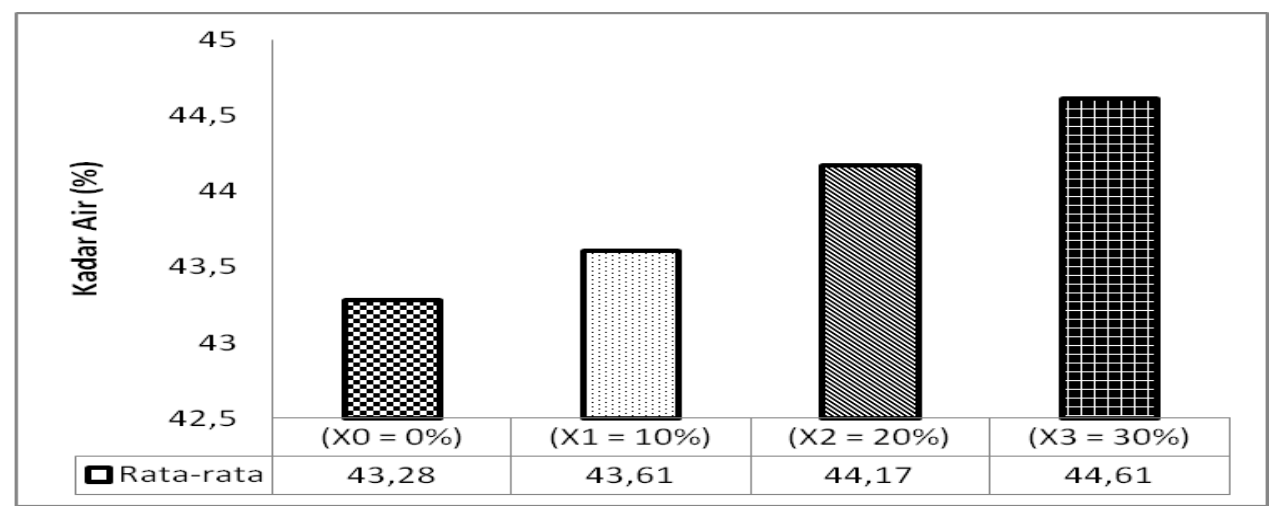

Gambar 5. Rata-rata Kadar Air Nugget Edamame 


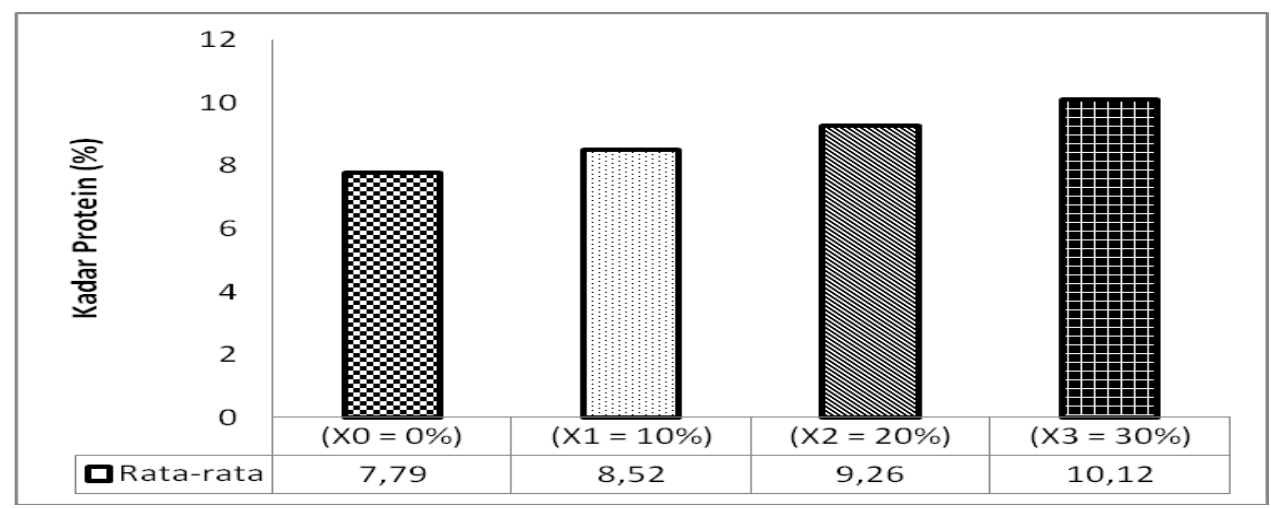

Gambar 6. Rata-rata Kadar Protein Nugget Edamame

dimana semakin tinggi kadar air maka semakin cepat terjadi kerusakan ${ }^{13}$. Kadar air maksimal yang terkandung dalam nugget menurut $\mathrm{SNI}$ 01-6683-2002 adalah 60\%, sedangkan 4 taraf perlakuan nugget edamame ini masih dapat diterima karena kadar airnya di bawah $60 \%$, yaitu $43,28 \%, 43,61 \%, 44,17 \%$, dan $44,61 \%$. Oleh karena itu, nugget edamame ini harus segera dikonsumsi dan tidak disimpan terlalu lama untuk menghindari terjadinya kerusakan.

\section{Kadar Protein}

Berdasarkan hasil uji laboratorium, diketahui bahwa nilai rata-rata kadar protein tertinggi adalah perlakuan $X_{3}(10,12 \%)$ dan nilai rata-rata terendah adalah perlakuan $X_{0}$ (7,79\%). Hasil uji kadar protein dapat dilihat pada Gambar 6.

Hasil statistik uji Kruskall-Wallis menunjukkan bahwa $p$-value $(0,003)<\alpha(0,05)$ sehingga $\mathrm{H}_{0}$ ditolak, artinya terdapat perbedaan kadar protein yang signifikan pada nugget edamame dengan atau tanpa penambahan tepung kacang tanah.

Nugget edamame dengan kadar protein tertinggi adalah $X_{3}$ dengan penambahan tepung kacang tanah $30 \%$. Apabila penambahan tepung kacang tanah meningkat, maka kadar protein juga akan meningkat. Peningkatan kadar protein dapat terjadi karena kandungan protein pada kedelai edamame yang ditambah dengan kandungan protein dari tepung kacang tanah. Kandungan protein kedelai edamame per 100 gram adalah 12,4 $\mathrm{gram}^{1}$, sedangkan kacang tanah sebanyak 27,9 gram $^{12}$. Peningkatan ini juga dapat terjadi karena kacang tanah mengandung sebesar $22 \%$ albumin yang merupakan jenis protein larut dalam air?

Kadar air dan kadar protein saling berhubungan. Ketika kadar air tinggi maka berat kering rendah, sehingga kadar protein dalam berat kering tersebut juga rendah ${ }^{3}$. Kadar air yang semakin tinggi, maka persentase protein akan menurun ${ }^{14}$. Akan tetapi, pada penelitian ini, kadar air akan meningkat seiring dengan peningkatan kadar protein.

Proporsi kedelai edamame, tepung tapioka, dan tepung kacang tanah memberikan pengaruh nyata terhadap kadar air dan kadar protein nugget edamame.

Berdasarkan uraian di atas, nugget edamame yang dapat disarankan untuk dikonsumsi adalah $X_{3}$. Perlakuan ini memiliki kandungan protein tertinggi yaitu $10,12 \% \mathrm{~b} / \mathrm{b}$, sedangkan menurut SNI 01-6683-2002 kandungan protein nugget minimal adalah $12 \% \mathrm{~b} / \mathrm{b}$. Berat satu potong nugget edamame sekitar 25 gram. Angka kecukupan protein anak usia 14-15 tahun adalah 69-72 gram. Nugget ini dapat dikonsumsi dua potong sehingga dapat memenuhi kecukupan protein anak sekitar 20,12 gram.

\section{KESIMPULAN}

Tepung kacang tanah dapat dijadikan bahan campuran pada proses pembuatan nugget edamame. Hasil uji daya terima nugget ini berbeda-beda. Nugget yang paling disukai dari segi rasa adalah nugget dengan penambahan tepung kacang tanah 30 gram, 
dari segi warna dan aroma adalah nugget tanpa penambahan tepung kacang tanah, dan dari segi tekstur adalah nugget dengan penambahan tepung kacang tanah 10 gram. Terjadi peningkatan kadar air dan kadar protein seiring dengan peningkatan jumlah penambahan tepung kacang tanah. Kadar air meningkat mulai dari $43,28 \%-44,61 \%$. Kadar protein meningkat mulai dari $7,79 \%-10,12 \%$. Proporsi penambahan tepung kacang tanah yang tepat dalam pembuatan nugget edamame terdapat pada $X_{3}$ dengan penambahan tepung kacang tanah $30 \%$.

Penelitian ini diharapkan dapat menjadi referensi penelitian selanjutnya terkait kandungan gizi yang lain dan daya simpan dari nugget edamame ataupun produk lain dari perpaduan kedelai edamame dan tepung kacang tanah, dengan memperhatikan standarisasi proses pengolahan. Selain itu juga diharapkan dapat membantu pemerintah dalam upaya sosialisasi pemanfaatan kedelai edamame agar bernilai ekonomi lebih tinggi dan menjadikannya salah satu alternatif lauk bagi penderita KEP dan vegetarian.

\section{ACKNOWLEDGEMENT}

Penghargaan diberikan penulis kepada seluruh staf pengajar Fakultas Kesehatan Masyarakat, Universitas Jember dukungan yang telah diberikan.

\section{REFERENSI}

1. Samsu. Membangun Agroindustri Bernuansa Ekspor dari Kedelai Jepang (Edamame) ke Sayur-mayur Beku. 2003. Available from http://www.bukuwakaf.com/wpcontent/uploads/2010/08/buku3_edamam e.pdf. Diakses pada 2 Oktober 2016. p. 2, 177.

2. Amar dan Lutfiati. Pengaruh Penggunaan Minyak Kedelai dan Susu Skim Terhadap Sifat Organoleptik Pasta Kedelai Edamame. E-Journal boga. Volume 2, Nomor 1, Edisi Yudisium Periode Februari 2013, Hal. 139149. Surabaya : Universitas Negeri Surabaya. 2013. Available from https://www.google.co.id/ejournal.unesa.a c.id. Diakses pada 8 Mei 2016.

3. Laksono, M. A., V. P. Bintoro dan S. Mulyani. Daya Ikat Air, Kadar Air, dan Protein Nugget Ayam yang Disubstitusi dengan Jamur Tiram Putih (Pleurotus Ostreatus). Animal Agriculture Journal, Vol.1 No.1, 2012, Hal. 685-696. Semarang : Universitas Diponegoro. 2012. Available from http://ejournals1.undip.ac.id/index.php/aaj. Diakses pada 31 Juli 2016.

4. Sciarappa, W.J. Edamame: The Vegetable Soybean. New Jersey : Rutgers Cooperative Research and Extension; 2004. p. 3.

5. Widati dan Iteu. Kedelai Sayur (Glycine max L. merill) sebagai Tanaman Pekarangan. 2012. Available from http://hortikultura.litbang.pertanian.go.id/ pdf. Diakses pada 31 Juli 2016.

6. Anggraini, A. dan Yunianta. Pengaruh Suhu dan Lama Hidrolisis Enzim Papian Terhadap Sifat Kimia, Fisik dan Organoleptik Sari Edamame. Jurnal Pangan dan Agroindustri Vol.3 No.3 Hal. 1015 - 1025, Juli 2015. Malang : Universitas Brawijaya Malang. Available from http://jpa.ub.ac.id/index.php/jpa/article/d ownload/224/231. Diakses pada 30 Desember 2016.

7. Rohaya, S., Husna, N., Bariah, K. Penggunaan Bahan pengisi Terhadap Mutu Nugget Vegetarian Bebahan Dasar Tahu dan Tempe. Jurnal Tekonologi dan Industri Pertanian Indonesia Vol.(5) No.1. 2013. Available from http://www.jurnal.unsyiah.ac.id/TIPI/articl e/view/997. Diakses pada 16 November 2016.

8. Setyaningsih, Apriyantoro, A., dan Puspitasari, M. Analisis Sensori untuk Industri Pangan dan Agro. Bogor : IPB Press; 2010. p. 9.

9. Sa'adah, E., Husna, N., Anggono, W., Suciani, E., dan Wahyuuni, R. Karakteristik Mie Kering Tersubstitusi Tepung Bungkil Kacang Tanah dengan Penambahan Getah Pepaya Kering (Carica Papaya L.) Terhadap Kualitas Fisitokimia dan Organoleptik. Jurnal Teknologi Pangan Vol.6 No.2, November 2015. Pasuruan : Universitas 
Yudharta Pasuruan. 2015. Available from http://jurnal.yudharta.ac.id. Diakses pada 31 Juli 2016.

10.Badan Standardisasi Nasional. Nugget Ayam : SNI 01-6683-2002. Jakarta : Badan Standardisasi nasional. 2002.

11.Karti, E., Latifah, dan Wulandari, E. Kajian Penambahan Tepung Tapioka dan Kuning Telur pada Pembuatan Bakso Daging Sapi. 2013. Available from download.portalgaruda.org.article.php. Diakses pada 30 Desember 2016.

12. Mahmud, Hermana, Zulfianto, Apriyantoro, Ngadiarti, Hartati, Bernadus, dan Tinexcelly. Tabel Komposisi Pangan
Indonesia. Jakarta : Elex Media Komputindo. 2009.

13.Winarno. Kimia Pangan dan Gizi. Jakarta : PT Gramedia Pustaka Utama; 2002. p. 84

14.Pramuditya, G. Penentuan Atribut Mutu Tekstur Bakso sebagai Syarat Tambahan dalam SNI dan Pengaruh Lama Pemanasan terhadap Tekstur Bakso. Jurnal Pangan dan Agroindustri Vol.2 No.4 Hal.200-209, Oktober 2014. Malang : Unviersitas Brawijaya Malang. Available from http://jpa.ub.ac.id/index.php/jpa/article/vi ewFile/92/110. Diakses pada 30 Desember 2016. 